\title{
Land Theft as Rural Eco-Crime
}

Rob White

Professor

School of Sociology and Social Work

Room 419 Arts Building

University of Tasmania, Australia

Hobart, Tasmania

Australia ABN 30764374782

R.D.White@utas.edu.au

Contact author: Rob White: ‥D.White@utas.edu.au; 61362262877

\begin{abstract}
Land grabbing in various forms is happening in many different parts of this globe. This involves 'outsiders' - nation-states as well as corporations - colluding with local domestic elites to radically alter existing land ownership and land uses. Contemporary forms of land theft take place under the guise of acquiring land for food and biofuels, and through imposition of resource extraction activities such as logging and mining. They also occur when land is sealed up for the purposes of carbon sequestration and for conservation. From the point of view of environmental justice, such land reconfigurations represent 'theft' insofar as they challenge the basic ways of life and subsistence abilities of traditional land owners. These stakeholders are generally vulnerable to land grabs by powerful interests, leading to immediate and longer term hardship. For green criminology, activity which diminishes social equity in the provision of healthy sustainable environments can be considered a type of ecocrime.
\end{abstract}

\section{Keywords: Land Theft, Land Grabbing, Environmental Justice, Green Criminology, Eco-crime, Conservation}




\section{Introduction}

The field of green criminology has grown rapidly over the past ten years and its further development is basically assured given the pressing issues of climate change, environmental degradation and rising levels of toxicity in the environment generally (White 2011). While mainstream criminology by and large focuses on street crime in urban areas, green criminology shifts the lens to environmental crimes, some of which take place in the oceans, the outback, the forests and the everglades. Thus green criminology frequently deals with events and situations in the so called 'rural and isolated' areas of the planet. Crimes such as illegal fishing, illegal logging and trade in endangered species, for example, are usually initially carried out in remote non-urban areas.

What happens in the rural and remote places of the planet nonetheless has huge ramifications for the quality of life and safety and security of those living in cities and towns, and vice versa. Urbanisation carries with it its own ills and problems - such as pollution and contamination of air, land and water - which are frequently transferred to the countryside by wind and river currents, as well as urban sprawl. Simultaneously, land use outside of urban centres has major implications for the food we eat, the shelter we construct, the relationships we forge with nature, and the extent of biodiversity within varied eco-systems. It also has implications for urbanisation itself insofar as changing land uses are linked to the push and pull factors of migration.

For those who live 'on the land' and rely on it for their livelihood, land use issues matter. The land is where they live, work, raise families and form lasting relationships with each other and with the natural world around them. What happens to the land, therefore, affects all who live on and with the land. Where proposed and new land use contradicts historical, cultural and established social purposes there is bound to be conflict.

The aim of this article is to examine land use issues from the point of view of environmental justice, an area of particular concern to green criminology (White 2008). Environmental justice refers to the distribution of environments among peoples in terms of access to and use of specific natural resources in defined geographical areas, and the impacts of particular social practices and environmental hazards on specific populations (e.g. as defined on the basis of class, occupation, gender, age, ethnicity). The main concern of environmental justice movements is with social equity (in which all individuals should have a right to be protected from environmental degradation) and harm prevention (the focus is on eliminating a threat before harm occurs) (see Bullard 2005).

This article argues that top-down and forced changes in land use, across several different dimensions, constitute a form of land theft that directly affects the health and wellbeing of traditional land dwellers and owners. According to a green criminology perspective, this represents a major environmental harm and injustice. Why and how this is so is explored in relation to selected case examples of land acquisition colloquially known as 'land-grabbing'. 


\section{Land and the Global Commons}

At the heart of many discussions of environmental justice is the question of land and land use. Whether informed by notions of self-interest and profit-motives, or paternalistic notions 'that we know best' about land management, there has been a general movement toward breaking down traditional land ownership and management schemes around the world. This occurs in several different ways, and involves a variety of domestic and international actors. For example, transnational corporations vary in how and under what circumstances they take over and utilise the natural resources of the planet. In some places, the appropriation of formerly communal or traditional lands is at the point of a gun, as companies hire thugs to remove and bulldoze people's home and villages (Robin 2010). Governments are also implicated in the systematic abuse of human rights involving the redesignation of traditional lands for the purposes of the 'national interest' (Clark 2009). Commonly held or communal property is thus being transformed into private or state-owned property, where land use is linked to capital accumulation and profit rather than subsistence and ecological balance. This is, in effect, expropriation.

Changing the status of land holdings can also be achieved through 'peaceful' means. For instance, the ideological shift toward privatisation, commodification and self-regulation under global neo-liberal policies is manifest in new forms of property relations as well as environmentally destructive activities (Harvey 2005). International competition amongst capitalist sectors and among communities for access to healthy or 'pristine' natural resources, including clean water, has also intensified because the natural resource base has shrunk. For companies, the agenda is also one of control over such resources. Under neo-liberal policies this can be achieved through market mechanisms and pressures (e.g., the buyer-seller nexus) which effectively allow international capitalist institutions to simply buy their way in to land appropriation. Neo-liberal policies also let them side-step state regulation and responsibility for achieving outcomes for the 'common good' once the land has been acquired.

Reforms in environmental management and regulation have also been closely linked to efforts by transnational corporations to further their hegemonic control over the planet's natural resources (Goldman 1998a,1998b). Markets may be protected through universalising environmental regulation (developed in and by the private sector, sometimes with NGO collusion, and later enforced by governments in the form of preferred contracts, and business legal requirements) that themselves advantage the high-technology, well financed companies of the advanced industrialised countries (Goldman 1998a,1998b). The largest companies are most likely to be capable of being environmentally 'virtuous' and thus to be granted rights and contracts related to natural resource extraction and use. To see environmental regulation in this light is to acknowledge the economic rather than ecological rationale behind the actions of global regulatory bodies like the World Trade Organisaton, International Monetary Fund and World Bank (see Friedrichs \& Friedrichs 2002). Such 'regulation' is about facilitation of the exploitation of nature and humans, not about human interests and needs and ecological wellbeing as such. Enhanced 'environmentally friendly' production and extraction of natural resources do not change the status quo - such enhancements still collectively degrade the global ecological commons. 
Non Government Organisations are divided as to how they should intervene in major world conservation and protection issues, and they are split as to whether they take action in collaboration with, or against, transnational corporations and hegemonic nation-states. Duffy (2010) points to the increasingly close relationships between large transnational NGOs and transnational corporations, international organizations such as the World Bank, and particular national governments. There is funding to be obtained and kudos found in many such arrangements. Conservation under these circumstances is re-defined as particular kinds of development rather than as out-and-out exploitation, and as an opportunity to land-grab for conservation purposes. Thus:

As new dam projects, oil fields, mines and tourism facilities threaten to engulf and destroy habitats and the wildlife they contain, conservation NGOs have spotted a new opportunity to push their agendas forward. Instead of resisting these new and potentially damaging initiatives, they work with developers on 'mitigation' projects. These revolve around deals with developers to 'offset', mitigate or compensate habitat loss by paying for or setting aside land for new conservation schemes and protected areas (Duffy 2010: 69).

This type of corporate-conservation collusion is not a new phenomenon. Jacoby (2001) describes how conservationists in the mid to late 1800s saw a strong link between their goals and development. The name of the game was efficiency and sustainable development, and the promise of conservation was to provide the continuous supply of the necessities of life.

Corporations likewise soon discovered that conservationist could be an ally in pursuit of their goals.

At the Grand Canyon, this close relationship between forestry officials and business interests began to take shape not long after the forest reserve's creation in 1893. By the early twentieth century, the canyon's new federal managers had reached a series of accommodations with the local mining, railroad, and lumber companies that allowed these businesses access to the reserve's natural resources (Jacoby 2001: 169).

In the twenty-first century new opportunities have emerged for conservation NGOs to work hand in glove with transnational corporations. Climate change, for example, has opened up new avenues for profitable offsets (e.g., forest as repositories for carbon sequestration under carbon emission trading schemes), many of which involve large NGOs.

\section{Land Theft through Changing Land Use}

The key features of contemporary land grabbing are rooted in the land-theft practices of the past, most notably those linked to colonialism and imperialism. Certain groups of people have histories of victimisation perpetrated through the imposition of colonial power. This was, at its heart, a matter of resource colonisation, a phenomenon that has affected many different Indigenous peoples in places such as South America, North America, and Australasia, as well as the native inhabitants of Africa, Asia and beyond. In countries such as 
Australia, Indigenous territories were considered frontier lands that were un-owned, underutilised and therefore open to exploitation. The prior ownership rights, interests and knowledge of Indigenous inhabitants were treated as irrelevant by the European invaders. Such disregard for the physical and cultural wellbeing of Indigenous people and their connection to 'country' was also evident in how they and their lands were treated when it came to nuclear testing. Indigenous people were effectively kicked off their land at Maralinga in South Australia, to allow the British to explode their bombs, and had nothing but polluted land to return to afterwards (White and Habibis 2005). Environmental victimisation is central to dispossession and maltreatment of Indigenous peoples across many continents and over a period of several centuries.

A key area of contemporary conflict, now and into the future, is around land use involving international forces and parties. Here a series of developments put into sharp focus the vested interests of specific industries, companies and nation-states - over and above the interests and needs of local communities. The contemporary food and financial crises have combined to trigger substantial changes in global land ownership (STWR 2009; Grain Briefing 2008). Much of this is being driven by both the direct impacts of climate change (i.e., the search for new sources of food production) and policy responses to climate change (e.g., carbon emission trading schemes). Systematic forms of injustice are being perpetrated under the guise of 'free market' opportunities, purported conservation-oriented agendas and strategic development.

\section{Planting and Harvesting}

There has been a rush to control land beyond a nation-state's borders to supply food and energy needs to sustain one's own population and society into the future (Robertson \& Pinstrup-Andersen 2010). The world food price crisis of 2007-2008 shocked some national governments of countries that were unable to produce sufficient food for their own populations. For example, the response of Middle East and Northern African countries, South Korea and India was to secure their own national food security by finding other lands that would support them (Borras \& Franco 2010). Large-scale agricultural investment is of benefit to transnational agribusiness (as opposed to small and medium sized farmers and pastoralists) and to governments such as China which import the food for its own population. Other countries become the directly controlled source of food for the country of origin. The result is a combination of commodification of food production, for export, involving industrial farming and mono-cropping. The 'winners' are the big companies, domestic elites and foreign governments. The 'losers' are local communities, small farmers and consumers of the host country. This type of land grabbing is not only occurring in economically vulnerable developing countries. In Australia, for example, there is increasing consternation over the large tracts of agricultural land being purchased by foreign investors (Morris 2012). Who should control food production is a familiar catchcry and of growing bio-security concern.

At the same time, communal lands are under threat from private and government pressures to introduce income-generating crops such as biofuels in Brazil, Argentina and other places (Robin 2010; Engdahl 2007; Shiva 2008). The problem here is twofold. Firstly, 
lands are being converted from food production to biofuel production, thereby reducing the amount of food available and leading to escalating prices for crops such as soya and corn (White 2008). Secondly, formerly communal lands are being forcibly seized by companies and/or governments and transferred into private hands. The 'ownership' as well as the use of the land is being re-jigged in favour of private interests and private profits. This is achieved not only by direct force, but by policies that reward biofuel production through subsidies and quota systems. The 'winners' are the new energy barons and their partners in government. Again, it is local consumers and communities that lose out. The search for and development of new energy sources, particularly in the light of peak oil and climate change pressures, provides major impetus to steal from those who otherwise depend for their subsistence on the land. In countries like Indonesia and Brazil, the profitability of biofuel production is leading to the establishment of large-scale plantations, the clearing of rainforests and in some instances the forcing of Indigenous peoples off their lands. This deforestation process has been going on for a number of years, supported by global organisations such as the International Monetary Fund and World Bank. Clearing of land for export-oriented cash crops has been touted as a key strategy to lift developing countries economic performance, but this is simply a guise for a particular sort of land grabbing that serves particular sectoral interests (French 2000).

Bioprospecting (the worldwide search for plants with special properties, such as for medicinal use) that is unregulated and inappropriate can be considered a form of overexploitation which has the potential to degrade ecosystems and increase biodiversity loss, as well as impacting on the rights of the communities and nation-states from which the resources are taken (see for example, Mgbeoji,2006). This form of bio-piracy involves taking from the land, and claiming ownership over what the land produces, without regard to the significant knowledge, traditions and contributions of traditional land holders. It entails the re-branding and patenting of aspects of the natural world in the interests of transnational corporations, with no recognition and acknowledgement of the prior relationships between the patented commodity (e.g., a nationally used bean) and the people who have traditionally harvested and utilised it (South 2007).

\section{Natural Resources and Extraction}

De-forestation is another example of changing land use. It is not just that grain production is changing in form (toward industrial) and content (toward biofuels), but so called 'unproductive' or forested lands are likewise being transformed on the basis of diverse profit-making ventures. These are not only agricultural in nature. For example, big disputes are occurring in the Amazon over the impact of mining and pastoral industries in relation to de-forestation (Boekhout van Solinge 2010a, 2010b). Land clearance is thus variously attributable to agricultural exploitation, cattle farming, mining, oil and gas installations, and hydroelectric dams (see Boekhout van Solinge 2008a, 2008b, 2010a, 2010b; Khagram 2004). Deforestation is also linked to the funding of civil wars and armed conflicts, and the phenomenon of 'conflict timber' in west Africa (Boekhout van Solinge 2008a). Vast amounts of forest are subject to destruction in different locations - from Peru and Brazil, and Liberia and Sierra Leone, to Indonesia and Australia. The purposes and motivations may vary, 
depending upon social context and industry interests, but the outcome is further depletion of many different kinds of trees and varieties of forests.

In other instances, land use that is dictated by the demands of mining companies is threatening the health and wellbeing of traditional owners regardless of claims that first-rate environmental regulation and management practices are in place. In the Northern Territory of Australia, for example, the Ranger uranium mine project has had devastating consequences for the local Mirarr people, but mining royalties and tax receipts seem to have a way of persuading authorities to ignore negative social impacts (Mudd 2008).

The contemporary resource wars against Indigenous peoples are significant in regards to scope, scale and impact (see Gedicks 2005). In Canada, for example, governments are eager to allow extraction industries to enter into and fully work lands occupied by Indigenous peoples, regardless of the wishes of the local people (Rush 2002; Smandych \& Kueneman, 2010). Meanwhile, in the US, the history of repression of Indigenous people is such that they were forcibly relocated to unwanted lands later found to contain some of the richest mineral deposits and other natural resources in the country (such as uranium and low-sulphur coal). One consequence of their forced removal to lands that are now wanted for their mineral wealth is that 'The quest for natural resources, then, imposes specific environmental risks on peoples such as Native Americans who reside near, and are dependent on, natural resources' (Field 1998: 80). On the other hand, pollution and contamination of water and fish in some regions directly undermines the capacity of Native American cultures and peoples to continue to function and thrive (Schlosberg 2007). At threat is not simply the immediate, physical needs of Indigenous and traditional peoples, but a whole way of life and livelihood that frequently includes hunting, fishing and small-scale agriculture. In the United States, for example, the Chippewa people have fought against mining operations on their lands, knowing that mining on their ceded lands would lead to environmental destruction of the land and water, thereby destroying their means of subsistence (Clark 2002). As with similar events elsewhere in the world, such contamination of the natural world constitutes an assault that goes to the heart of Indigenous culture and identity.

In the developed countries there is much consternation and controversy over the environmental impact of 'fracking', a technique that involves using chemicals to extract coal seam gas. In the United States, for example, a major concern is that hydraulic fracturing fluids used to fracture rock formations contain numerous chemicals that can harm human health and the environment, especially if they enter drinking water supplies. A recent report found that:

Between 2005 and 2009, the oil and gas service companies using hydraulic fracturing products contained 29 chemicals that are (1) known or possible human carcinogens, (2) regulated under the Safe Drinking Water Act for their risks to human health, or (3) listed as hazardous air pollutants under the Clean Air Act (United States House of Representatives, 2011). 
It was also noted that in many instances the companies were injecting fluids containing chemicals that they themselves could not identify. The main protagonists in the fracking debate are, on the one side, coal and gas companies, and on the other farmers and environmentalists. Profit and power are the key determinants in these debates, as is the extent of community mobilisation and politicisation of the issues.

Contamination arising from certain production methods is not confined to the site of production itself. For instance, materials such as e-waste are being shipped to peripheral areas and countries for processing and disposal (White 2008; Pellow 2007). This involves basically using land as a dumping ground. This is occurring mainly in Africa and Asia, as the West searches for places to dispose of the residues, garbage and toxins left over from production and consumption. Other types of dumping are happening as well, often on Aboriginal land. The forced or co-opted loss of Indigenous control of their land is not only related to carbon sequestration and the push to plant biofuels, but is also associated with the establishment of nuclear waste dumps and disposal of hazardous wastes more generally (Boylan 2010). Consistent with the general pattern of environmental victimisation, it is the most vulnerable who are likely to suffer from both take-over of land and radical alterations to existing land uses. Likewise, this type of 'garbage imperialism' feeds upon those who seek fiscal relief in the very moment that it sustains a racist and classist culture and ideology that views toxic dumping on poor communities of colour as perfectly acceptable (Pellow 2007).

\section{Nature Reserves and Conservation}

Lands in less developed countries are also being appropriated by governments, companies and conservation groups, ostensibly for purposes of ecological sustainability and climate change mitigation. For example, certain businesses are keen to secure money as part of carbon sequestration schemes, usually involving companies based in Europe offsetting their pollution by buying carbon credits in the form of forests in other parts of the world. For others, the motivation is ecological, rather than financial, at least in intent. Examples here include Western conservation groups and movements that both historically and today are usurping the lands of traditional and Indigenous peoples in the name of conservation (Jacoby 2003; Duffy 2010). Corporate funding largesse to mainstream conservation groups also contributes to the overall strategy, one that disenfranchises traditional owners and users from their own lands.

Several trends are of note in regard to conservation and the environmental social movements that support it. First, while it is the case that 'Currently, 13 per cent of land and less than 1 per cent of oceans are protected for conservation' (UNEP 2011: 12), there is great pressure to lock up more lands for conservation purposes worldwide. Second, there is increasing concern about how NGOs from 'outside' (i.e., the metropoles of the North) impact upon the status and livelihoods of those in certain parts of the world (i.e., those who actually live in the South). Duffy (2010) recounts how in a number of cases transnational NGO action has translated into the criminalisation of local residents and alienation from their own lands and natural resources. There is a 'dark side' to conservation that is based upon cultural ignorance and that can, in its own right, create more harm than good and lead to both human 
misery and unsustainable ecological solution. In many cases, conservationists have been pitted against traditional users of forests and lands.

In Africa, for instance, traditional practices are being undermined by imposition 'from above' by the establishment of national parks and reserves in ways that disenfranchise locals from their customary lands. These land acquisitions are having major negative impacts on local people who are losing access and control over the resources on which they depend, and which are the rightful inheritance of future generations. The take-over and take-away of land are compounded by the ways in which 'conservation' regulations are being foisted upon these same communities. As Duffy (2010: 11) points out:

When wildlife reserves are established, local communities can suddenly find that their everyday subsistence activities have been outlawed and they have been redefined as criminals....Some of the world's best-known pristine wilderness areas are, in fact, engineered environments. Creating a national park means drawing up new conservation rules which outlaw the everyday subsistence activities of local communities, such as hunting for food and collecting wood.

These transformations of land use metamorphoses victims into offenders, a phenomenon that is by no means novel or restricted to any one continent or time period. The person who has been dispossessed of their land and who has no access to natural resources already faces a huge and daunting task to survive - to be subjected to ill treatment and placed in prison constitutes an additional harm that further violates their basic rights.

\section{Land Theft as a Significant Rural Crime}

There are different cultural understandings and meanings attached to 'land' and 'country' that reflect traditional, cultural and livelihood interests. However, where the dominant social construction of 'property' sees it as a relationship of exclusive use based upon documented ownership, then any sense of a 'commons' and universal interests is diminished. Moreover, in the context of rhetoric supporting the 'national interest', there is also impetus for commercial production to take place on formally considered 'public lands', including in some cases what has ordinarily been treated as 'traditional' shared lands. Indeed this is the biggest target for worldwide land grabs and includes, for example, the majority of land in Africa, Indonesia and the Philippines. The land grabs described above are for all intents and purposes not simply about governance, but about the very basis of land sovereignty - the effective control over the nature, pace, extent and direction of surplus production, distribution and disposition (Borras \& Franco 2010). It is about ownership and control over land resources.

Land grabbing is occurring at the hands of many different agents, and for different purposes worldwide. Not all of the changes to land use are 'bad'; in some exceptional circumstances, for example, industrial production has been transformed back into small-scale production designed for local consumption and sustainable living (Borras \& Franco 2010). It is essential to acknowledge the complexities of these changes in land use by closely 
considering how land is being reconfigured, by whom and for what purposes (see also Robertson \& Pinstrup-Andersen 2010). Importantly, transnational corporations and 'foreign' governments are not the only or even necessarily always the central players in the expropriation of land and in the land use shuffle. National bourgeoisie and state elites are also willing partners in the plunder, and may well encourage foreign investment and take-overs as a major platform of economic development. The 'national interest' is linked with the idea of 'bio-security' in ways that ideologically and materially tend to prop up the most powerful sectors of state and private enterprise.

Who is most negatively affected by land theft is partly a function of what can be exploited, where it is located, and how much resistance is likely to be encountered.

Multinational mining, oil, and logging corporations are now using advanced exploration technology, including remote sensing and satellite photography, to identify resources in the most isolated and previously inaccessible parts of the world's tropical rain forests, mountains, deserts, and frozen tundras. What the satellites don't reveal is the fact that native peoples occupy much of the land containing these resources. (Gedicks 2005: 168).

Nations with the greatest dependency on food aid, and with the largest percentage of their population suffering from undernourishment, are increasingly net sellers of farmland (Robertson \& Pinstrup-Andersen 2010: 272).

In a shrinking world, the search for 'green fields' for new development and for the exploitation of additional natural resources is intensifying and brings into play new technologies that facilitate ever greater extraction and processing of the Earth, at a scale and pace never seen before.

There are several dimensions of land theft, as described above, that directly and indirectly relate to conceptualisations of crime and criminality. For example, there are crimes associated with illegal felling of trees and illegal land clearance that are simultaneously accompanied by destruction of animal habitats. These are 'traditional' environmental crimes, as are those pertaining to illegal theft of plants and wildlife. More recently, water theft is beginning to figure more prominently in the repertoire of such crimes, as irrigation issues and access to water become heightened in periods of drought and in the face of climate change. Pollution and contamination issues are likewise of rising concern as waste is produced, consumer packaging and older commodities are discarded, and 'solutions' to the problem are sought across borders and outside of normal legal constraints.

In terms of conventional crime, fraud linked to carbon trading and misreporting of carbon offsets pose problems, as does the unauthorised planting and use of genetically modified crops (Walters 2011; White 2011). Land theft may involve outright thuggery, including homicide, on the part of the disreputable and the powerful alike. Corruption of state 
officials may underpin implementation of general shifts in land use, and allow denigration of the rights of those who resist such changes.

Contemporary forms of land theft take place under the guise of acquiring land for food and biofuels, and through imposition of resource extraction activities such as logging and mining. They also occur when land is sealed up for the purposes of carbon sequestration and for conservation. From the point of view of environmental justice, such land reconfigurations represent 'theft' insofar as they challenge the basic ways of life and subsistence abilities of traditional land owners. These stakeholders are generally vulnerable to land grabs by powerful interests, leading to immediate and longer term hardship that directly impact the health and wellbeing of those dependent upon the targeted land for a living. Threats to subsistence, especially in the light of no or inadequate compensation, means that men, women and children will suffer in the same moment that powerful corporations, local businesses and state elites reap the reward of changing land uses. The strategies used to achieve these changes include but are not limited to varying levels of moral and financial corruption, use of coercion and violence, and outright theft and fraud.

Environmental injustice is intrinsic to the social and power dynamics of rural and remote areas around the globe. For green criminology, activity which diminishes social equity in the provision of healthy sustainable environments can be considered a type of ecocrime. This article argues that land theft is one type of rural eco-crime that is of particular concern, especially given that the majority of the world's population still lives outside of cities and is dependent upon what the land will provide. Specifically, it has outlined different types of land grabbing, motivated by different economic and political agendas, which have had negative social consequences for the traditional owners and users of the land. Exploitation of the environment and of people goes hand in hand, and where this occurs, social justice is undermined accordingly.

Environmental justice is precisely about questions of equity and intergenerational reproduction in the context of individual, group and community health and wellbeing. Land theft constitutes a major threat to diverse groups of people around the world, both in the hereand-now and into the future. It is a global crime that demands closer analysis and a social response. Green criminology can contribute to both. 


\section{References}

Boekhout van Solinge, T. 2008a. Crime, conflicts and ecology in Africa. In R. Sollund (ed) Global Harms: Ecological Crime and Speciesism. New York: Nova Science Publishers.

Boekhout van Solinge, T. 2008b. The land of the Orangutan and the Bird of Paradise under threat. In R. Sollund (ed), Global Harms: Ecological Crime and Speciesism. New York: Nova Science Publishers.

Boekhout van Solinge, T. 2010a. Equatorial deforestation as a harmful practice and a criminological issue. In R. White (ed), Global Environmental Harm: Criminological Perspectives. Devon: Willan Publishing.

Boekhout van Solinge, T. 2010a. Deforestation crimes and conflicts in the Amazon. Critical Criminology, 18, 263-277.

Borras, S. \& Franco, J. 2010. Towards a Broader View of the Politics of Global Land Grab: Rethinking Land Issues, Reframing Resistance. ICAS Working Paper Series No.001. Published jointly by Initiatives in Critical Agrarian Studies, Land Deal Politics Initiative and Transnational Institute.

Boylan, J. 2010. Australia's aboriginal communities clamour against uranium mining. The Guardian. United Kingdom. 9 August, 2010. <http://www.guardian.co.uk/environment/2010/aug/09/austrailia-aboriginal-uraniummining $>$ (accessed October 2010)

Bullard, R. (ed) 2005. The Quest for Environmental Justice: Human Rights and the Politics of Pollution. San Francisco: Sierra Club Books.

Clark, B. 2002 The indigenous environmental movement in the United States. Organization \& Environment, 15, 410-442.

Clark, R. 2009. Environmental disputes and human rights violations: a role for criminologists. Contemporary Justice Review, 12, 129-146.

Duffy, R. 2010. Nature Crime: How We're Getting Conservation Wrong. New Haven: Yale University Press.

Engdahl, F. 2007. Seeds of Destruction: The Hidden Agenda of Genetic Manipulation. Montreal: Global Research. 
Field, R. 1998. Risk and justice: Capitalist production and the environment. In D. Faber (ed), The Struggle for Ecological Democracy: Environmental Justice Movements in the US. New York: Guilford Press.

French, H. 2000. Vanishing Borders: Protecting the Planet in the Age of Globalization. New York: WW Norton \& Company.

Friedrichs, D. \& Friedrichs, J. 2002. The World Bank and crimes of globalization: A case study. Social Justice, 29,13-36.

Gedicks, A. 2005. Resource wars against native peoples. In R. Bullard (ed), The Quest for Environmental Justice: Human Rights and the Politics of Pollution. San Francisco: Sierra Club Books.

Goldman, M. 1998a Introduction: The political resurgence of the commons. In M. Goldman (ed), Privatizing Nature: Political Struggles for the Global Commons. London: Pluto Press in association with Transnational Institute.

Goldman, M. 1998b. Inventing the commons: Theories and practices of the commons' professional. In M. Goldman (ed), Privatizing Nature: Political Struggles for the Global Commons. London: Pluto Press, in association with Transnational Institute.

Grain Briefing 2008. Seized! The 2008 land grab for food and financial security October 2008. <http://www.grain.org/briefings_files/landgrab-2008-en.pdf> (accessed September 2010)

Harvey, D. 2005. A Brief History of Neoliberalism. Oxford: Oxford University Press.

Jacoby, K. 2003. Crimes Against Nature: Squatters, Poachers, Thieves, and the Hidden History of American Conservation. Berkeley: University of California Press.

Khagram, S. 2004. Dams and Development: Transnational Struggles for Water and Power. Ithaca, NY: Cornell University.

Mgbeoji, I. 2006. Global Biopiracy: Patents, Plants, and Indigenous Knowledge. Vancouver: UBC Press.

Morris, S. 2010. Coalition to limit foreign buyers. The Australian Financial Review, Friday 2 March 2012, p.3.

Mudd, G. 2008. Environmental regulation of uranium mining on indigenous land surrounded by a World Heritage-listed national park: A brief review of the ranger uranium project. National Environmental Law Review, 2, 36-42. 
Pellow, D. 2007. Resisting Global Toxics: Transnational Movements for Environmental Justice. Cambridge: The MIT Press.

Robertson, B. \& Pinstrup-Andersen, P. 2010 Global land acquisition: neo-colonialism or development opportunity? Food Security 2, 271-283.

Robin, M. M. 2010. The World According to Monsanto: Pollution, Corruption and the Control of Our Food Supply. New York: The New Press.

Rush, S. 2002. Aboriginal Resistance to the Abuse of Their National Resources: The Struggles for Trees and Water. In S. Boyd, D. Chunn \& R. Menzies (eds), Toxic Criminology: Environment, Law and the State in Canada. Halifax: Fernwood Publishing.

Schlosberg, D. 2007. Defining Environmental Justice: Theories, Movements, and Nature. Oxford: Oxford University Press.

Share the Worlds Resources (STWR) 2009. Land Grabbing the End of Sustainable Agriculture?. < http://www.stwr.org/food-security-agriculture/land-grabbing-the-endof-sustainable-agriculture.html> (accessed October 2010).

Shiva, V. 2008. Soil Not Oil: Environmental Justice in an Age of Climate Crisis. Brooklyn: South End Press.

Smandych, R. \& Kueneman, R. 2010 'The Canadian-Alberta tar sands: a case study of statecorporate environmental crime', in R. White (ed) Global Environmental Harm: Criminological Perspectives. Devon: Willan Publishing.

South, N. 2007. The "corporate colonisation of nature": Bio-prospecting, bio-piracy and the development of green criminology. In P. Beirne \& N. South (eds), Issues in Green Criminology: Confronting Harms Against Environments, Humanity and Other Animals. Devon: Willan.

United Nations Environment Programme 2011. UNEP Year Book: Emerging Issues in Our Global Environment 2011. Nairobi, Kenya: UNEP.

United States House of Representatives Committee on Energy and Commerce Minority Staff 2011. Chemicals Used in Hydraulic Fracturing. Washington, DC: US House of Representatives.

Walters, R. 2011. Eco Crime and Genetically Modified Food. New York: Routledge.

White, R. 2008. Crimes Against Nature: Environmental Criminology and Ecological Justice. Devon: Willan Publishing. 
International Journal of Rural Criminology, Volume, 1, Issue 2 (November), 2012

White, R. 2011. Transnational Environmental Crime: Toward an Eco-Global Criminology. London: Willan/Routledge.

White, R. \& Habibis, D. 2005. Crime and Society. Melbourne: Oxford University Press. 